\title{
Nitrification of Urea and Assimilation of Nitrate in Saturated Soils Under Aerobic Conditions
}

\author{
A.E. Ghaly and V. V. Ramakrishnan \\ Department of Process Engineering and Applied Science, Dalhousie University, Halifax, Nova Scotia, Canada B3J 2X4. \\ Received 2013-10-01; Revised 2013-10-14; Accepted 2013-11-04
}

\begin{abstract}
The aim of this study was to investigate nitrification activity of urea and the assimilation of nitrate in a well aerated soil using perfusion technique with addition of glucose as an energy and carbon source. In this study, urea was rapidly nitrified by the bacteria in the saturated soil but its course of transformation to $\mathrm{NO}_{3}$ was not linear. There was an initial increase in the concentration of nitrite during the nitrification experiment which indicated that the conversion of nitrite to nitrate was appreciably slower than the rate of conversion of urea to nitrite. The rate of conversion of $\mathrm{NH}_{4}{ }^{+}$to $\mathrm{NO}_{2}{ }^{-}$was faster than the rate of conversion of $\mathrm{NO}_{2}{ }^{-}$to $\mathrm{NO}_{3}{ }^{-}$in the first 12 days and as a result the nitrate concentration reached 2.72 $\mu \mathrm{g} / \mathrm{ml}$ on the $12^{\text {th }}$ day. After day 12 , the concentration of $\mathrm{NH}_{4}{ }^{+}$in solution declined significantly and the rate of conversion of $\mathrm{NO}_{2}^{-}$to $\mathrm{NO}_{3}^{-}$became faster than the rate of conversion of $\mathrm{NH}_{4}^{+}$to $\mathrm{NO}_{2}^{-}$. The concentration of $\mathrm{NO}_{2}-\mathrm{N}$ in the solution reached zero on the $23^{\text {rd }}$ day. The nitrification curve has the character of a sigmoid curve whose midpoint, which representing the most rapid rate of nitrification, fell at the point of half conversion of urea to nitrite. The curve asymptotically approaches a nitrate value that represents $98 \%$ conversion of urea into nitrate. The rest of the urea $\left(\mathrm{NH}_{4}\right)$ has presumably been synthesized into bacterial cells. The initial $\mathrm{pH}$ of the soil was 7.7 due to the presence of $\mathrm{NH}_{4}$ which decreased gradually due to the production of $\mathrm{NO}_{3}$ reaching 6.9 by day 23 . A nitrate reduction was observed under aerobic conditions. Denitrification did not proceed according to the known fact that $\mathrm{O}_{2}$ prevents the denitrifying organisms from producing the enzyme responsible for the process. The alternative pathway for nitrate reduction could be by assimilatory reduction where nitrate was converted to ammonium and then to cells. The removal of nitrate and production of ammonium caused a rise in the $\mathrm{pH}$. The initial $\mathrm{pH}$ of the solution was 6.9 which increased with time reaching 7.3 by the $7^{\text {th }}$ day. The expected nitrate reduction was $50 \%$ according to the assumption, but the $59 \%$ nitrate reduction observed in the experiment suggests that more than $25 \%$ of glucose $\mathrm{C}$ was metabolized and less than $75 \%$ was oxidized, otherwise.
\end{abstract}

Keywords: Deamination, proteins, amino acids, urea, ammonium, nitrite, nitrate, nitrification, denitrification, nitrate assimilatory reduction

\section{INTRODUCTION}

The overall transformations of nitrogen in which microorganisms are involved range from nitrogen gas to protein and other complex organic nitrogenous

Corresponding Author: Ghaly, A.E., Department of Process Engineering and Applied Science, Dalhousie University, Halifax, Nova Scotia, B3J 2×4, Canada. Email: abdel.ghaly@dal.ca

compounds with a tremendously large array of substrates between these extremes (Figure 1). A great many intricate enzymatic reactions are involved in bringing about these changes (Cranfield et al., 2010; Jetten, 2008; Robertson and Kuenen, 1990; Keeney, 1973). 


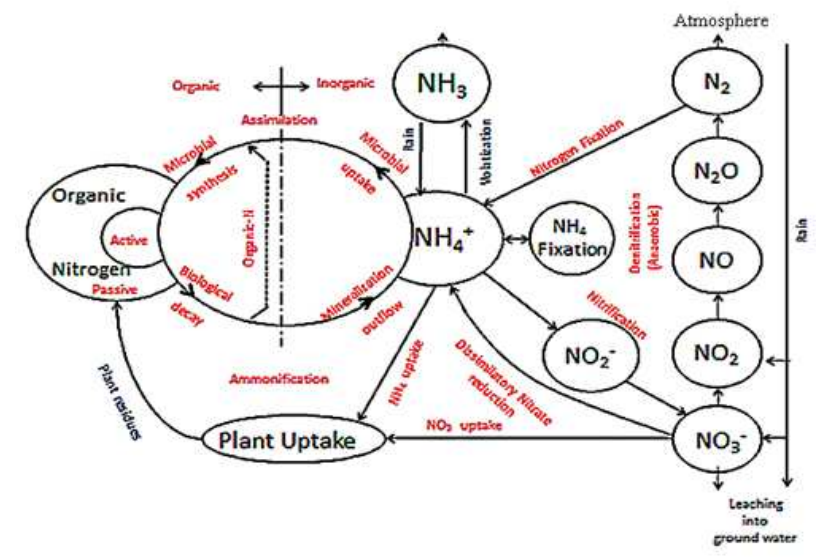

Fig 1. Organic and inorganic forms of nitrogenous compounds and transformation pathways.

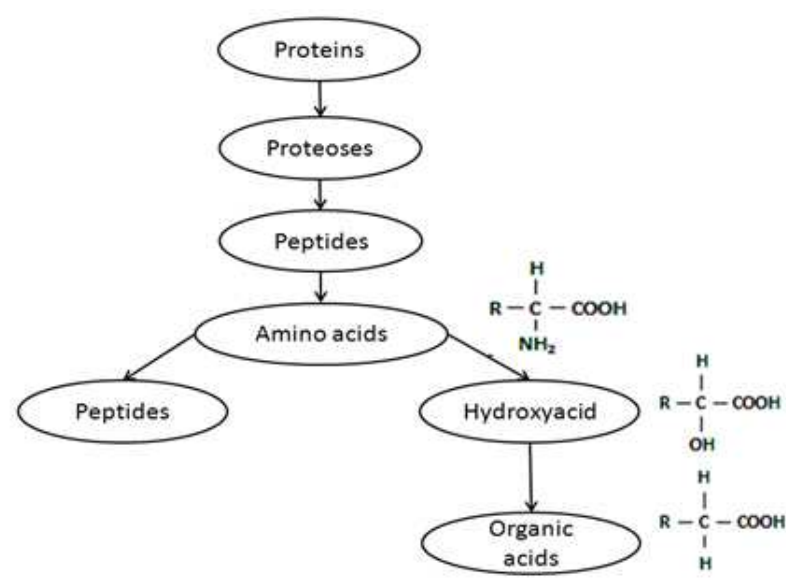

Fig 2. Breakdown of proteins.

The nitrogen in proteins may be regarded as the end of the line as far as the synthesis of nitrogenous compounds is concerned. In order to set this organically bound nitrogen free for recirculation, the first process that must take place is the enzymatic hydrolysis of protein which is called deproteinization or protein degradation. It is accomplished by microorganisms capable of elaborating extracellular enzymes that convert the protein to smaller units of peptides which are then attacked by peptidases resulting ultimately in the release of amino acids and ammonium (Fuka et al., 2009; Hofmockel et al., 2010). The breakdown of proteins is shown in Figure 2 and the overall reaction may be summarized as follows:
Protein $\stackrel{\text { Proteinases }}{\longrightarrow}$ Peptides $\stackrel{\text { Peptidases }}{\longrightarrow}$ Amino Acid

Amino acids are either utilized as nutrients or degraded by microorganisms in a process called deamination. Deamination is the process of removing amino group with the production of ammonia and organic acids. The production of ammonia is referred to as ammonification (Fuka et al., 2009; Jetten, 2008; Hofmockel et al., 2010). An example of specific deamination-ammonification is as follows:

$$
\begin{gathered}
\mathrm{CH}_{3} \mathrm{CHNH}_{2} \mathrm{COOH} \\
\text { Alanine }
\end{gathered}
$$

Many bacterial and fungi species and actinomycetes elaborate large amounts of proteolytic enzymes (Table 1). Among bacteria, the most active are Clostridium species (Clostridium histolyticum and Clostridium sporogenes). A lesser degree of activity is found in Pseudomonas and Bacillus (Kamala-Kannan et al., 2010; Kunert, 1982; Gottlieb and Ciferri, 1956; Bentley, 1953; Takikawa et al., 1979; Challa et al., 1999).

The process of oxidation of ammonium to nitrate is called nitrification. From the stand point of soil fertility, nitrate in the soil provides the form of nitrogen most bioavailable to plants. Nitrification is carried out in two stages by. two autotrophic bacterial species (nitrite forming bacteria and nitrite oxidizing bacteria) which cooperate to produce the final product of nitrate anion from the ammonium cation as follows (Cranfield et al., 2010; Jetten, 2008; Lin et al., 2009; Li et al., 2013):

Oxidation of ammonia to nitrite

$$
\mathrm{NH}_{4}^{+}+1 \frac{1}{2} \mathrm{O}_{2} \stackrel{\text { Nitrosomonas }}{\longrightarrow} \mathrm{HNO}_{2}^{-}+\mathrm{H}_{2} \mathrm{O}+2 \mathrm{H}^{+}
$$

Oxidation of nitrite to nitrate

$$
\mathrm{NO}_{2}+\frac{1}{2} \mathrm{O}_{2} \stackrel{\text { Nitrobacter }}{\longrightarrow} \mathrm{NO}_{3}
$$

The nitrification capacity in soil is significantly affected by the variation of strain of the bacteria, type of soil and soil conditions such as $\mathrm{pH}$, temperature, moisture content and oxygen concentration (Fuka et al., 2009). Lin et al. (2009) reported a narrow range of viable $\mathrm{pH}$ of 7.8-8.0 with a fairly rapid fall off on each side. 
A.E. Ghaly and V.V. Ramakrishnan / American Journal of Agricultural and Biological Science 8 (4): 330-342, 2013

Table 1. Microorganisms capable of producing deamination enzymes (Kamala-Kannan et al., 2010; Kunert, 1982; Gottlieb and Ciferri, 1956; Bentley, 1953; Ohshima et al., 1978; Ohshima et al., 1991 and Challa et al., 1999).

\begin{tabular}{llc}
\hline Bacteria & Fungi & Actinomycetes \\
\hline Acidovorax avenae & Aspergillus oryzae & Streptomyces species \\
Bacillus Species & Candida albicans & Streptomyces fradiae \\
Bacillus stephaericus & Microsporum canis & Streptomyces lavendulae \\
Bacillus stearothermophilus & Microsporum gypseum & Streptomyces venezulae \\
Bacillus megaterium & Trichophyton species & Streptomyces globosus \\
Burkholderia terricola & Trichophyton mentagrophytes & Streptomyces filipinensis \\
Clostridium species & Trichophyton rubrum & Streptomyces atrovirens \\
Clostridium histolyticum & Ustilago hordei & Streptomyces albovinaceus \\
Clostridium sporogenes & & Thermoactinomyces intermedius \\
Enterobacter cloacae & & \\
Klebsiella oxytoca & & \\
Methylibium petroleiphilum & & \\
Pseudomnas species & & \\
Pseudomonas fluorescens & & \\
Pseudomonas plecoglossicida & & \\
Pseudomonas putida & & \\
Pseudomonas syringae & & \\
Ralstonia pickettii & & \\
Variovorax paradoxus & & \\
\hline
\end{tabular}

Ammonium disappearance and $\mathrm{NO}_{3}$ accumulation were reported to be more rapid at $25^{\circ} \mathrm{C}$ than at $10^{\circ} \mathrm{C}$ (Warneke et al., 2011). Higher rates of nitrification are expected to occur in shallower water relative to the rates of nitrification occurring in deeper water where lower water temperatures exist. Aeration (availability of oxygen) is an important factor affecting nitrification (Billen, 1976). Chen et al. (1972) reported that nitrification occurs in the first 5 to $20 \mathrm{~cm}$ of lake sediments where considerable mixing takes place.

Bacteria capable of completing anaerobic ammonium oxidation (referred to as "anammox") have been reported in literature (Jetten, 2008; Lin et al., 2009; Cranfield et al., 2010). Lin et al. (2009) stated that this reaction occurs primarily in aquatic environments, predominantly by the organisms Planctomycetes. In anaerobic ammonium oxidation, nitrogen gas and water are produced from ammonium and nitrite as follows:

$$
\mathrm{NH}_{4}^{+}+\mathrm{NO}_{2}^{-} \rightarrow \mathrm{N}_{2}+2 \mathrm{H}_{2} \mathrm{O}
$$

Certain microorganisms are capable of transforming nitrate to nitrous oxide and nitrogen gas under anaerobic conditions by a process called denitrification which leads to a net loss of nitrogen from the soil. The autotrophic organism Thiobacillus denitrificans and the heterotrophic organisms Micrococcus denitrificans,
Preudomonas and Archomobacter are responsible for bringing about this process (Torrento et al., 2010; Kim et al., 2008; Bergaust et al., 2009; Lin et al., 2009; Smith et al., 1972).

$$
\mathrm{NO}_{3} \rightarrow \mathrm{NO}_{2} \rightarrow \mathrm{NO} \rightarrow \mathrm{N}_{2} \mathrm{O} \rightarrow \mathrm{N}_{2}
$$

Assuming availability of substrate $\left(\mathrm{NO}_{3}{ }^{-}\right.$or $\left.\mathrm{NO}_{2}{ }^{-}\right)$, the rate and extent of denitrification is controlled by the availability of oxygen and energy source (Fuka et al., 2009). In denitrification, nitrate serves as the terminal exogenous $\mathrm{H}$ acceptor for the oxidation of organic substances. The reaction appears to be coupled with specific enzymes and cofactors. The oxidation of glucose by $\mathrm{NO}_{3}$ under anaerobic conditions is as follows (Delwiche and Finstein, 1965):

$\mathrm{C}_{6} \mathrm{H}_{12} \mathrm{O}_{6}+4 \mathrm{NO}_{3} \rightarrow 6 \mathrm{CO}_{2}+6 \mathrm{H}_{2} \mathrm{O}+2 \mathrm{~N}_{2}$

The practice of soil fertilization with manure depends on the microbial mineralization of organic matter and the conversion of organic nitrogen to nitrate through ammonification and the process of nitrification. However, irrigation with dilute solutions of urea and ammonium, which is one of the modern methods used for fertilization, is a more direct means by which nitrate content in soil is increased through oxidation of ammonium (Robertson and Vitousek, 2009). 


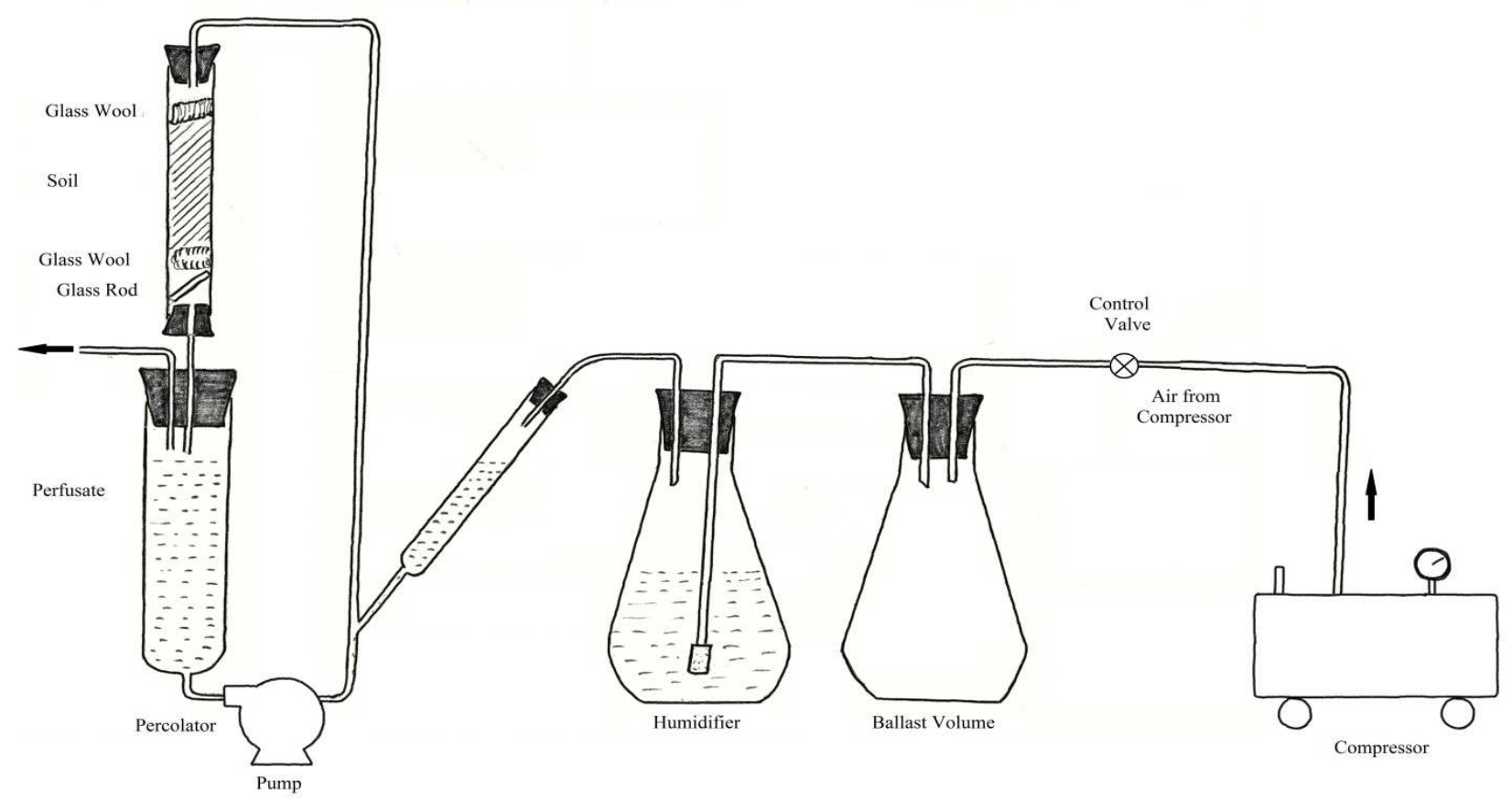

Fig 3. Perfusion Apparatus

\section{OBJECTIVES}

The aim of this study was to investigate the nitrification activity of urea and the assimilation of the end product $\mathrm{NO}_{3}^{-}$in a well aerated soil using the perfusion technique with the addition of glucose as a carbon and energy source. The specific objectives were: (a) to study the nitrification of urea by following nitrite appearance and nitrate accumulation, (b) to determine whether there is partial or complete conversion of urea into nitrate and (c) to study the possibility of assimilating the produced nitrate from the nitrification process with addition of glucose as a carbon and energy source by following the nitrate disappearance.

\section{MATERIALS AND METHODS}

\subsection{Perfusion Apparatus}

The perfusion apparatus consists of a column of sieved soil (about $50 \mathrm{~g}$ ) held in a vertical glass tube of 5 $\mathrm{cm}$ diameter by means of glass wool plug placed under the soil column and above a small glass rod as shown in Figure 3. A small quantity of aerated fluid containing the metabolites was continually taken from a reservoir by a pump (Masterflex L/S, Cole-Parmer Instruments, Montreal, Quebec, Canada) and ran on to the top of the soil column where it percolated downward through the soil column dissolving soluble substances on its way to the reservoir. The air was supplied by a compressor (Shanborn model MCIFC 75-715, Coleman Powermate, Springfield, Minnesota, USA) and passed through a 2000 $\mathrm{ml}$ empty Erlenmeyer flask which acted as a ballast volume. The air flew from the ballast flask, entered into another $2000 \mathrm{ml}$ Erlenmeyer flask containing $1500 \mathrm{ml}$ pure water, diffused through the water (to be humidified) and then entered to the percolator.

\subsection{Experimental Procedure}

\subsubsection{Nitrification}

The percolator was assembled and connected to the air supply. Fifty grams of fresh weight of soil was mixed thoroughly with $5 \mathrm{~g}$ of calcium carbonate and placed in the upper tube of the percolator while the perfusate was placed in the lower tube. The perfusate consisted of 180 $\mathrm{ml}$ of water in which urea was dissolved to give $100 \mu \mathrm{g}$ $\mathrm{N} / \mathrm{ml}$ of water. The pump was started and the perfusate 
percolated through the soil. The course of transformation of urea was followed by taking samples of the perfusate at 2 day intervals for $\mathrm{pH}$, nitrite and nitrate analyses.

\subsubsection{Nitrate Assimilation}

After the nitrification process was completed, the assimilation of $\mathrm{NO}_{3}$ produced from the nitrification process was investigated. The perfusate was taken out of the percolator and the volume was measured. To calculate the quantity of glucose required to theoretically immobilize the $\mathrm{NO}_{3}{ }^{-} \mathrm{N}$, two assumptions were made: (a) the bacterial cell dry weight contains $50 \%$ carbon and $10 \%$ nitrogen $(\mathrm{C}: \mathrm{N}=5: 1)$ and (b) $75 \%$ of the glucose will be oxidized (respired) to produce the energy needed for growth while $25 \%$ will be immobilized (assimilated) into microbial cells. Therefore, to convert $100 \mu \mathrm{g} \mathrm{NO}-\mathrm{N}$ into $100 \mathrm{~g}$ cell $\mathrm{N} / \mathrm{ml}$, the required amount of glucose was estimated as follows:

$$
\text { Required glucose }=\frac{100 \times 5 \times 4}{1 \times 1}=2000 \mu \text { g glucose } / \mathrm{mL}
$$

Since $105 \mathrm{ml}$ perfusate was left in the percolator, the required amount of glucose was estimated to be $0.21 \mathrm{~g}$ ( $2000 \times 105=210000 \mu \mathrm{g}$ glucose or $0.21 \mathrm{~g}$ glucose $)$. Since $0.21 \mathrm{~g}$ of glucose will give rise to the immobilization of $100 \mathrm{~g} \mathrm{NO}_{3}^{-} \mathrm{N} / \mathrm{ml}, 0.105 \mathrm{~g}$ glucose was required. The perfusate containing glucose was returned to the percolator. The pump was started and the perfusate percolated through the soil. Samples were removed daily for nitrate determination.

\subsection{Experimental Analyses}

\subsubsection{Determination of $\mathrm{NO}_{2}-\mathrm{N}$}

The nitrate analysis was carried out according to the diazotization method described in the Standard Methods of Examination of Water and Waste water (APHA, 1990). The nitrite concentration was determined through the formation of a reddish purple azo dye produced at a $\mathrm{pH}$ of 2.0-2.5 by the coupling of diazotized sulfanilic acid with naphthylamide dihydrochloride.

Sulphanilamide solution was prepared by dissolving $10 \mathrm{~g}$ of sulphanilamide in a mixture of $100 \mathrm{ml}$ of concentrated $\mathrm{HCl}$ and $600 \mathrm{ml}$ of distilled $\mathrm{H}_{2} \mathrm{O}$. The mixture was diluted to $1000 \mathrm{ml}$ with distilled $\mathrm{H}_{2} \mathrm{O}$. N-(LNaphtyl)-Ethylenediamine Dihydrochloride solution was prepared by dissolving $1.0 \mathrm{~g}$ of dihydrochloride in 1000 $\mathrm{ml}$ of distilled $\mathrm{H}_{2} \mathrm{O}$. The solution was stored in a dark bottle.

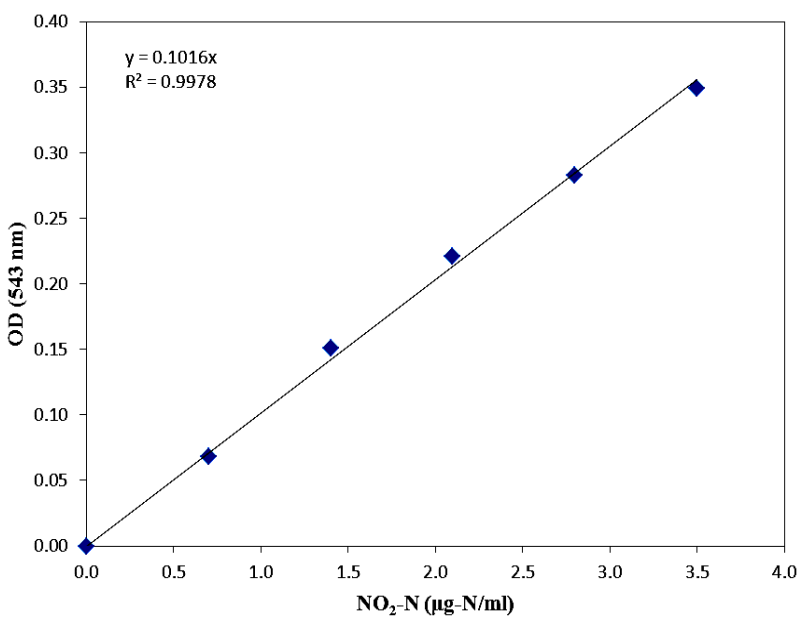

Fig 4. $\mathrm{NO}_{2}^{-}$standard curve.

A standard sodium nitrite solution was prepared by dissolving $5.229 \mathrm{~g}$ of $\mathrm{NaNO}_{2}$ in distilled water and diluting to $1000 \mathrm{ml}$.

A standard curve was prepared by transferring 0.0 , $0.1,0.2,0.3,0.4$ and $0.5 \mathrm{ml}$ of the standard sodium nitrite solution into 5 test tubes. Distilled water was added to each test tube to bring the volume to $5 \mathrm{ml}$. Then, $0.5 \mathrm{ml}$ each of the sulphanilamide and N-(LNaphtyl)-ethylenediamine dihydrochloride solution were added. The tubes were mixed on a vortex (Maxi Mix I, Type 16700, Barnstead Thermolyne, Dubuqe, Indiana, U.S.A.) and a reddish color was allowed to develop. Then, the optical density was measured against a blank at $543 \mathrm{~nm}$ using a spectrophotometer (Genesys 20, Thermo Scientific, Mississauga, Ontario, Canada). The standard curve was developed by plotting the optical density against the nitrite nitrogen concentration as shown in Figure 4.

Samples of $0.5 \mathrm{ml}$ of the perfusate were taken at time intervals and diluted to $10 \mathrm{ml}$ with distilled water. To determine the perfusate nitrite concentration, $0.5 \mathrm{ml}$ of each reagent (sulphanilamide and N-(L-Naphtyl)ethylenediamine dihydrochloride) was added to $5 \mathrm{ml}$ of the perfusate in a test tube and mixed on the vortex. After the red color had developed, the optical density was measured at $543 \mathrm{~nm}$ against a blank and the nitrite concentration was determined from the standard curve.

\subsubsection{Determination of $\mathrm{NO}_{3}-\mathrm{N}$}

The nitrate analysis was carried out according to the phenoldisulphonic acid methods described in the 
Standard Methods of Examination of Water and Wastewater (APHA, 1990). The nitrite concentration was determined through the development of a yellow color by the reaction between nitrate and phenodisulfonic acid. The reaction follows Beer's Law up to $12 \mathrm{mg} / \mathrm{L} \mathrm{N}\left(60 \mathrm{mg} / \mathrm{L}\right.$ of $\left.\mathrm{NO}_{3}\right)$ at a wave length of $420 \mathrm{~nm}$.

The phenoldisulfonic acid reagent was prepared by dissolving $25 \mathrm{~g}$ of pure white phenol in $150 \mathrm{ml}$ of concentrated $\mathrm{H}_{2} \mathrm{SO}_{4}$ and then adding $75 \mathrm{ml}$ of fumic $\mathrm{H}_{2} \mathrm{SO}_{4}\left(15 \%\right.$ free $\left.\mathrm{SO}_{3}\right)$. The solution was well mixed and then heated for $2 \mathrm{~h}$ in a hot water bath. A $1.0 \mathrm{~N}$ sodium hydroxide solution was prepared by dissolving $39.997 \mathrm{~g}$ of $\mathrm{NaOH}$ in $1000 \mathrm{ml}$ distilled $\mathrm{H}_{2} \mathrm{O}$. A $10 \%$ hydrogen peroxide solution was prepared by dilution $28.6 \%$ of $35 \% \mathrm{H}_{2} \mathrm{O}_{2}$ to $100 \mathrm{ml}$ with distilled water. A saturated calcium hydroxide solution was prepared by dissolving $\mathrm{Ca}(\mathrm{OH})_{2}$ in $1 \mathrm{~L}$ of distilled water until the water becomes saturated. A standard sodium nitrate solution of $100 \mu \mathrm{g}$ $\mathrm{NO}_{3}{ }^{-} \mathrm{N} / \mathrm{ml}$ was prepared by dissolving $36.97 \mathrm{mg} \mathrm{NaNO}_{3}$ in $1000 \mathrm{ml}$ distilled water.

A standard curve for nitrate was prepared by adding $0.10,0.25,0.50,0.75$ and $1.0 \mathrm{ml}$ of the standard $\mathrm{NaNO}_{3}$ solution to five $125 \mathrm{ml}$ Erlenmeyer flasks. Each sample was diluted to $1.0 \mathrm{ml}$ by adding distilled water to the flasks. To each flask, 1 drop of saturated $\mathrm{Ca}(\mathrm{OH})_{2}$ and $0.3 \mathrm{ml}$ of $10 \%$ hydrogen peroxide were added. The flasks were dried at $103^{\circ} \mathrm{C}$ for $30 \mathrm{~min}$ Then, $1 \mathrm{ml}$ of phenoldisulphonic acid solution was added and thoroughly mixed. After allowing the solution to sit for $20 \mathrm{~min}, 14 \mathrm{ml}$ of distilled $\mathrm{H}_{2} \mathrm{O}$ and $35 \mathrm{ml}$ of $1 \mathrm{~N}$ $\mathrm{NaOH}$ were added to each flask and the yellow color was allowed to develop. The optical density was measured at420 nm using a spectrophotometer (Genesys 20, Thermo Scientific, Mississauga, Ontario, Canada) against a reagent blank. The standard curve was developed by plotting the optical density against nitrate nitrogen concentration as shown in Figure 5.

Samples of $0.5 \mathrm{ml}$ of the perfusate were taken at time intervals and diluted to $10 \mathrm{ml}$ with distilled water. To measure the nitrate concentration in the perfusate samples, $1.0 \mathrm{ml}$ of the diluted samples was transferred into an Erlenmeyer flask and 1 drop of saturated $\mathrm{Ca}(\mathrm{OH})_{2}$ and $0.3 \mathrm{ml}$ of $10 \%$ hydrogen peroxide were added. The solution was dried in an oven at $103^{\circ} \mathrm{C}$ for 30 min. Then, $1 \mathrm{ml}$ of phenoldisulphonic acid was added and thoroughly mixed. After waiting for 20 minutes, 14 $\mathrm{ml}$ of distilled water and $35 \mathrm{ml}$ of $1.0 \mathrm{NaOH}$ were added and the yellow color was allowed develop.

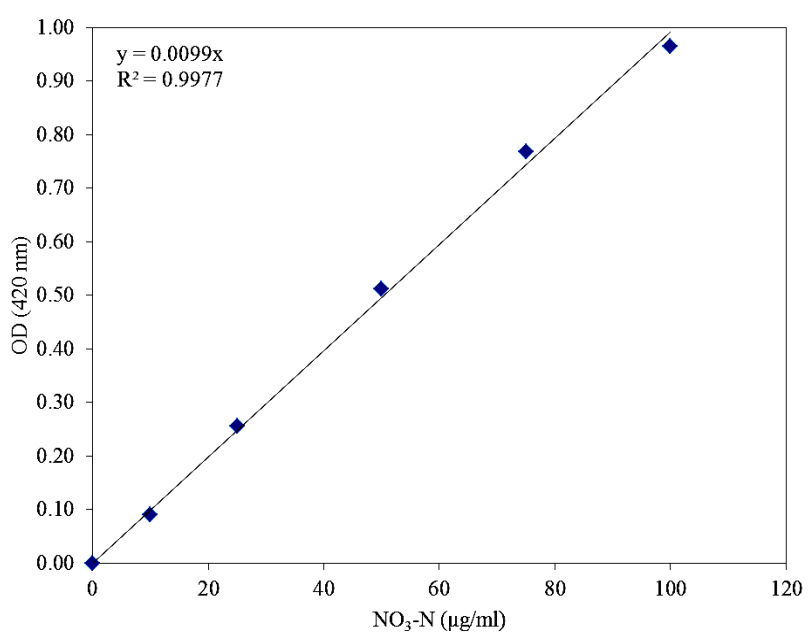

Fig 5. $\mathrm{NO}_{3}{ }^{-}$standard curve.

The optical density was measured at $420 \mathrm{~nm}$ using a spectrophotometer (Genesys 20, Thermo Scientific, Mississauga, Ontario, Canada) against a reagent blank. The nitrate nitrogen concentration was determined from the standard curve.

\subsection{3. pH Monitoring}

About $15 \mathrm{ml}$ of the perfusate were placed in a $20 \mathrm{ml}$ beaker and the $\mathrm{pH}$ was measured by a $\mathrm{pH}$ meter (Model $805 \mathrm{MV}$, Fisher Scientific, Montreal, Quebec). The sample was returned into the percolator.

\section{RESUTLS AND DISCUSSION}

\subsection{Nitrification}

The $\mathrm{pH}, \quad \mathrm{NO}_{2}-\mathrm{N}$ and $\mathrm{NO}_{3}-\mathrm{N}$ measurements are presented in Table 2. The results indicated that urea was nitrified very rapidly by the nitrifying bacteria present in the soil into $\mathrm{NO}_{3}$. Since oxidation of $\mathrm{NH}_{4}{ }^{+}$to $\mathrm{NO}_{3}{ }^{-}$in soil is a two stage process (nitrite being an intermediate product) as shown in Equations 3 and 4 and no initial nitrite was found in the nitrifying soil, it was assumed that the rate of conversion of nitrite to nitrate can be used as a measure of the rate of converting urea to $\mathrm{NH}_{4}^{+}$.

The initial $\mathrm{pH}$ of the soil was 7.7 due to the presence of $\mathrm{NH}_{4}$ which decreased gradually as result of $\mathrm{NO}_{3}$ production reaching 6.9 by the $23^{\text {rd }}$ day as shown in Figure 6. Simek and Cooper (2002) reported that all the nitrogen transformations in the soil are affected by $\mathrm{pH}$ and nitrogen transformations can also cause changes in the soil $\mathrm{pH}$. 
A.E. Ghaly and V.V. Ramakrishnan / American Journal of Agricultural and Biological Science 8 (4): 330-342, 2013

Table 2. Nitrite and nitrate appearance with time during nitrification process

\begin{tabular}{cccc}
\hline $\begin{array}{l}\text { Time } \\
(\text { days })\end{array}$ & $\mathrm{pH}$ & $\begin{array}{c}\mathrm{NO}_{2}-\mathrm{N} \\
(\mu \mathrm{g} / \mathrm{ml})\end{array}$ & $\begin{array}{c}\mathrm{NO}_{3}-\mathrm{N} \\
(\mu \mathrm{g} / \mathrm{ml})\end{array}$ \\
\hline 0 & 7.7 & 0.00 & 0.00 \\
2 & 7.7 & 0.15 & 6.20 \\
5 & 7.6 & 0.50 & 20.50 \\
7 & 7.5 & 1.06 & 34.50 \\
9 & 7.4 & 1.78 & 50.00 \\
12 & 7.3 & 2.72 & 67.50 \\
14 & 7.2 & 1.34 & 80.00 \\
16 & 7.1 & 0.20 & 86.00 \\
21 & 7.0 & 0.01 & 95.50 \\
23 & 6.9 & 0.00 & 98.00 \\
26 & 6.9 & 0.00 & 98.00 \\
28 & 6.9 & 0.00 & 98.00 \\
\hline
\end{tabular}

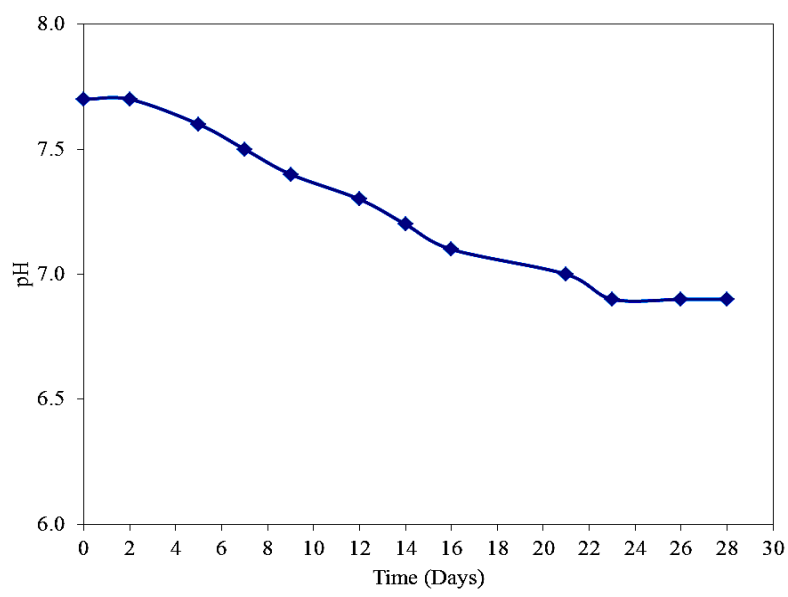

Fig 6. $\mathrm{pH}$ measurement during the nitrification process

During nitrification, the nitric acid produced can reduce the $\mathrm{pH}$ of the soil. In contrast, the generation of oxidized pyridine nucleotides and ammonium during dissimilatory reduction of nitrate $\left(\mathrm{NO}_{3}\right)$ and respiratory denitrification causes increases in the $\mathrm{pH}$ of the soil.

Sahrawat et al. (1985) studied the effect of $\mathrm{pH}$ on the rate of aerobic conversion of ammonium in six different soils and found no nitrate formation in the soils with $\mathrm{pH}$ levels less than 5. Sahrawat (2008) reported that soil $\mathrm{pH}$ plays an important role in the nitrification process within the range of 5.5-10.0, with the optimum $\mathrm{pH}$ being 7.5. Kyveryga et al. (2004) studied the effects of $\mathrm{pH}$ on nitrification process of ammonia applied into the soil for corn growth and found no nitrification below $\mathrm{pH} 5$ and the nitrification proceeded at a rapid rate in the soils with $\mathrm{pH}$ greater than 6.0.

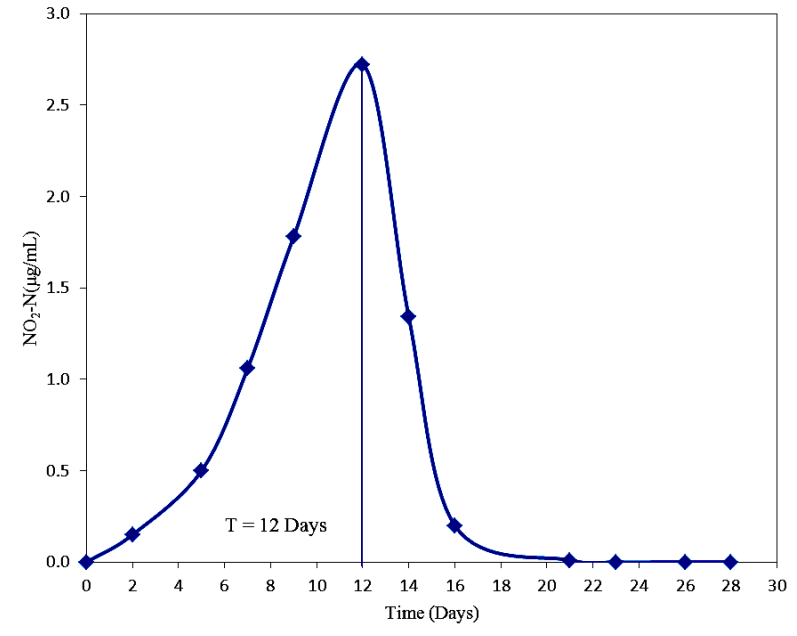

Fig 7. Nitrite $\left(\mathrm{NO}_{2}-\mathrm{N}\right)$ measurement during the nitrification process.

Sahrawat (1982) studied the nitrification process in 10 different soils at $30^{\circ} \mathrm{C}$ for a period of 4 weeks and noticed that a $\mathrm{pH}$ less than 5 did not support nitrification. At $\mathrm{pH} 5.6$, the nitrification produced only $5 \mathrm{mg}$ Nitrate$\mathrm{N} / \mathrm{kg}$ soil while at $\mathrm{pH} 6,7.5$ and 8.6 the nitrification proceeded at rapid rates and released 116, 123 and 118 $\mathrm{mg}$ nitrate-N/kg of soil, respectively. The highest nitrification activity was found at $\mathrm{pH}$ 7.5. The optimum $\mathrm{pH}$ for nitrification process was within the range of 6.97.7 observed in this study.

The nitrate- $\mathrm{N}$ accumulation curve is shown in Figure 7. Initially the rate of conversion of $\mathrm{NH}_{4}^{+}$to $\mathrm{NO}_{2}^{-}$was faster than the rate of conversion of $\mathrm{NO}_{2}{ }^{-}$to $\mathrm{NO}_{3}{ }^{-}$in the first 12 days and as a result the nitrate concentration reached $2.72 \mu \mathrm{g} / \mathrm{ml}$ on the $12^{\text {th }}$ day. Thereafter, the concentration of $\mathrm{NH}_{4}{ }^{+}$in solution declined significantly (became less than half of the initial concentration) and the rate of conversion of $\mathrm{NO}_{2}{ }^{-}$to $\mathrm{NO}_{3}{ }^{-}$became faster than the rate of conversion of $\mathrm{NH}_{4}^{+}$to $\mathrm{NO}_{2}^{-}$and as result the concentration of $\mathrm{NO}_{2}-\mathrm{N}$ in the solution reached zero on the $23^{\text {rd }}$ day.

Venterea and Rolston (2000) studied soil nitrification for 20 days and determined populations and growth rates of Nitrobacter and Nitrosomonas. The results indicated that the oxidation of ammonia resulted in a rapid accumulation of nitrite and a constant reduction of ammonia in the soil. The maximum accumulation of nitrite was reached on the $7^{\text {th }}$ day, after which the amount 
of nitrite began to decline and reached zero on the $20^{\text {th }}$ day. At the start of the nitrification process, the formation of nitrate from nitrite oxidation was slower than the formation of nitrite from ammonia oxidation due to the initial lack of nitrite in the soil. After day 7, the rate of conversion of $\mathrm{NO}_{2}{ }^{-}$to $\mathrm{NO}_{3}{ }^{-}$became faster than the rate of conversion of $\mathrm{NH}_{4}^{+}$to $\mathrm{NO}_{2}^{-}$.

Smith et al. (1997) observed nitrite accumulation in soils having three moisture contents (40, 50 and 60\%) after the addition of urea and potassium nitrate. The results indicated that hydrolysis of urea took place in the first 2 days of incubation which resulted in an increase in the $\mathrm{pH}$ of the soil. During the $\mathrm{NO}_{2}{ }^{-}$accumulation, the rate of conversion of $\mathrm{NH}_{4}{ }^{+}$to $\mathrm{NO}_{2}{ }^{-}$. was faster than the rate of conversion of $\mathrm{NO}_{2}^{-}$to $\mathrm{NO}_{3}^{-}$. The accumulation of $\mathrm{NO}_{2}^{-}$ proceeded and reached its peak on the $6^{\text {th }}$ day for all the moisture contents after which the amount of nitrite began to decline and reached zero on the $10^{\text {th }}$ day.

The nitrate production rate was dependent on the rate of converting $\mathrm{NH}_{4}$ to $\mathrm{NO}_{2}$. The nitrate accumulation with time is shown in Figure 8. The nitrate curve has roughly the character of a sigmoid curve whose midpoint (that representing the most rapid rate of nitrification) falls at the point of half conversion of urea into $\mathrm{NO}_{3}{ }^{-}$. The initial stage of the curve is approximately exponential. Then, as the saturation begins, the production of $\mathrm{NO}_{3}$ slows and finally stops. The curve asymptotically approached a nitrate value that represents about $98 \%$ conversion of urea into nitrate. The rest of the urea $\left(\mathrm{NH}_{4}\right)$ has presumably been synthesized into bacterial cells as shown in the following equation.

$$
5 \mathrm{CO}_{2}+\mathrm{NH}_{4}^{+} \rightarrow \mathrm{C}_{5} \mathrm{H}_{7} \mathrm{O}_{2} \mathrm{~N}+\mathrm{H}^{+}
$$

Although there are many expressions to logistic curves, the logistic (autocatalytic) sigmoid curve describing nitrate accumulation can be represented by the following equation:

$$
\log \left(\frac{\mathrm{Y}}{\mathrm{A}-\mathrm{Y}}\right)=\mathrm{K}\left(\mathrm{T}_{1}-\mathrm{T}_{2}\right)
$$

Where:

$\mathrm{Y}=$ nitrate $-\mathrm{N}$ produced $(\mu \mathrm{g} / \mathrm{g}$ soil $)$

$\mathrm{A}=$ asymptotic value approached by $\mathrm{Y}(\mu \mathrm{g} / \mathrm{g}$ soil $)$

$\mathrm{T}_{1}=$ time from start of perfusion (days)

$\mathrm{T}_{2}=$ Time of half completion (When: $\mathrm{Y}=1 / 2 \mathrm{~A}$ )

$\mathrm{K}=$ constant

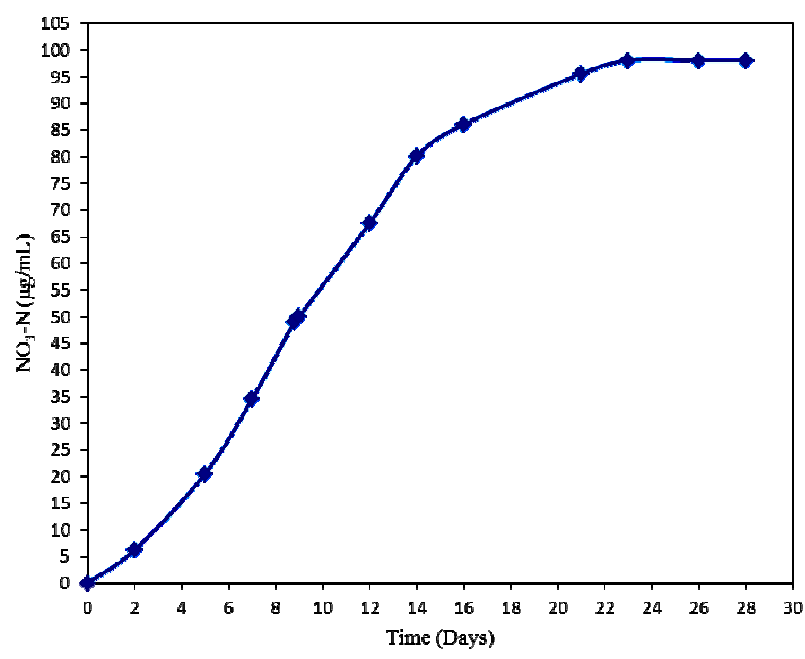

Fig 8. Nitrate $\left(\mathrm{NO}_{3}-\mathrm{N}\right)$ measurement during the nitrification process.

The equation is characteristic of an autocatalytic unimolecular reaction which expresses the fact that the velocity of such reaction at any instant is proportional to the amount of material undergoing changes and the amount of material already transformed. The nitrate accumulation rate approaches its maximal when the rate of nitrite appearance reached the maximum level. The nitrate concentration continued to increase but at a decreasing rate due to the decrease in nitrite (and/or $\mathrm{NH}_{4}^{+}$) concentration. The $\log \left(\frac{\mathrm{Y}}{\mathrm{A}-\mathrm{Y}}\right)$ values at different times $\left(\mathrm{T}_{1}\right)$ were calculated as shown in Table 3. The straight line obtained by plotting $\log \left(\frac{\mathrm{Y}}{\mathrm{A}-\mathrm{Y}}\right)$ against $\mathrm{T}_{1}$ is shown in Figure 9. The constant $\mathrm{K}$ and time from the start of perfusion $T_{1}$ were estimated from the curve and used to plot the logistic curve. The $\mathrm{K}$ and $\mathrm{T}$ values were 0.137 and 9.5 days, respectively. The calculations for the theoretical curve are shown in Table 4. The fit of theoretical logistic curve to the curve drawn for the results obtained from the experiment is shown in Figure 10.

Van Cleemput and Samater (1996) reported that nitrite accumulation in the soil is due to the slow rate of growth of Nitrobacter bacteria, which catalyses the oxidation of nitrite $\left(\mathrm{NO}_{2}{ }^{-}\right)$to nitrate $\left(\mathrm{NO}_{3}^{-}\right)$, compared to the growth rate of the Nitrosomonas bacteria, which catalyses the oxidation of ammonia $\left(\mathrm{NH}_{4}{ }^{+}\right)$to nitrite $\left(\mathrm{NO}_{2}{ }^{-}\right)$. 
A.E. Ghaly and V.V. Ramakrishnan / American Journal of Agricultural and Biological Science 8 (4): 330-342, 2013

Table 3. Determination of $\log \left(\frac{\mathrm{Y}}{\mathrm{A}-\mathrm{Y}}\right)$.

\begin{tabular}{cccc}
\hline $\begin{array}{c}\mathrm{T}_{1} \\
\text { days })\end{array}$ & $\begin{array}{c}\mathrm{Y} \\
\left(\mu \mathrm{g} \mathrm{NO}_{3} / \mathrm{ml}\right)\end{array}$ & $\left(\frac{\mathrm{Y}}{\mathrm{A}-\mathrm{Y}}\right)$ & $\log \left(\frac{\mathrm{Y}}{\mathrm{A}-\mathrm{Y}}\right)$ \\
\hline 0 & 0.00 & 0.000 & \\
1 & 4.00 & 0.043 & -1.371 \\
2 & 6.20 & 0.068 & -1.170 \\
3 & 12.00 & 0.140 & -0.855 \\
4 & 16.00 & 0.195 & -0.710 \\
5 & 20.50 & 0.265 & -0.578 \\
6 & 29.00 & 0.420 & -0.376 \\
7 & 34.50 & 0.543 & -0.265 \\
8 & 42.00 & 0.750 & -0.125 \\
9 & 50.00 & 1.042 & 0.018 \\
10 & 56.00 & 1.333 & 0.125 \\
11 & 62.00 & 1.722 & 0.236 \\
12 & 67.50 & 2.213 & 0.345 \\
13 & 73.50 & 3.000 & 0.477 \\
14 & 78.00 & 3.900 & 0.591 \\
15 & 82.00 & 5.125 & 0.710 \\
16 & 86.00 & 7.167 & 0.855 \\
17 & 88.00 & 8.800 & 0.944 \\
18 & 90.50 & 12.067 & 1.082 \\
19 & 92.00 & 15.333 & 1.186 \\
20 & 93.50 & 20.778 & 1.318 \\
21 & 95.50 & 38.200 & 1.582 \\
22 & 97.00 & 97.000 & 1.987 \\
23 & 98.00 & & \\
\hline
\end{tabular}

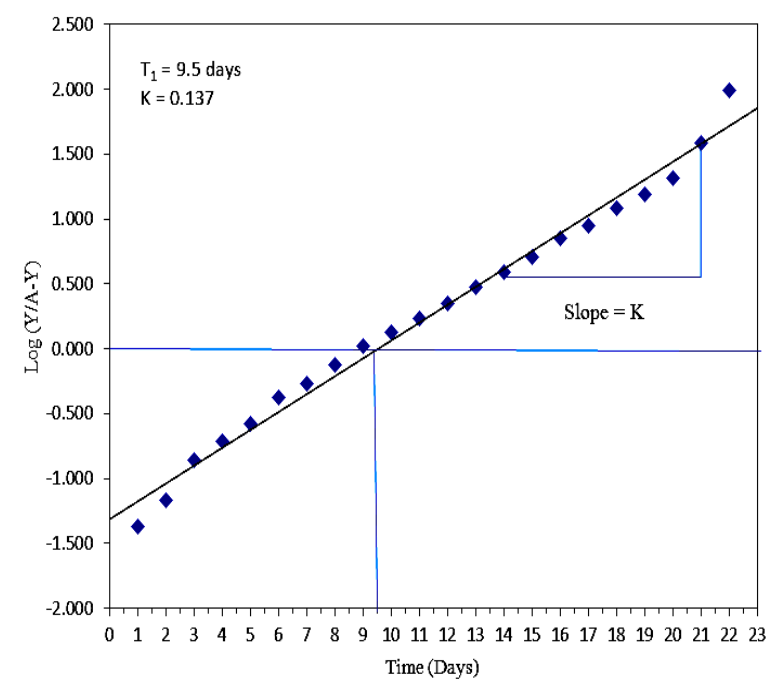

Fig 9. Variance of $\log \left(\frac{\mathrm{Y}}{\mathrm{A}-\mathrm{Y}}\right)$ with time.
Table 4. Theoretical Nitrate accumulation as calculated from logistic curve with time.

\begin{tabular}{ccccc}
\hline $\begin{array}{c}\mathrm{T}_{1} \\
\text { (days) }\end{array}$ & $\mathrm{T}_{1}-\mathrm{T}_{2}$ & $\mathrm{~K}\left(\mathrm{~T}_{1}-\mathrm{T}_{2}\right)$ & $\left(\frac{\mathrm{Y}}{\mathrm{A}-\mathrm{Y}}\right)$ & \\
\hline 0 & & & $\mathrm{Y}^{*}$ \\
1 & -9.5 & -1.3015 & 0.0499 & 4.66 \\
2 & -8.5 & -1.1645 & 0.0684 & 6.28 \\
3 & -7.5 & -1.0275 & 0.0938 & 8.41 \\
4 & -6.5 & -0.8905 & 0.1286 & 11.17 \\
5 & -5.5 & -0.7535 & 0.1764 & 14.70 \\
6 & -4.5 & -0.6165 & 0.2418 & 19.08 \\
7 & -3.5 & -0.4795 & 0.3315 & 24.40 \\
8 & -2.5 & -0.3425 & 0.4544 & 30.62 \\
9 & -1.5 & -0.2055 & 0.6230 & 37.62 \\
10 & -0.5 & -0.0685 & 0.8540 & 45.14 \\
11 & 0.5 & 0.0685 & 1.1708 & 52.86 \\
12 & 1.5 & 0.2055 & 1.6050 & 60.38 \\
13 & 2.5 & 0.3425 & 2.2003 & 67.38 \\
14 & 3.5 & 0.4795 & 3.0164 & 73.60 \\
15 & 4.5 & 0.6165 & 4.1352 & 78.92 \\
16 & 5.5 & 0.7535 & 5.6689 & 83.30 \\
17 & 6.5 & 0.8905 & 7.7714 & 86.83 \\
18 & 7.5 & 1.0275 & 10.653 & 89.59 \\
19 & 8.5 & 1.1645 & 14.604 & 91.72 \\
20 & 9.5 & 1.3015 & 20.021 & 93.34 \\
21 & 10.5 & 1.4385 & 27.447 & 94.56 \\
22 & 11.5 & 1.5755 & 37.627 & 95.46 \\
23 & 12.5 & 1.7125 & 51.582 & 96.14 \\
\hline & 13.5 & 1.8495 & 70.713 & 96.63 \\
\hline & & & &
\end{tabular}

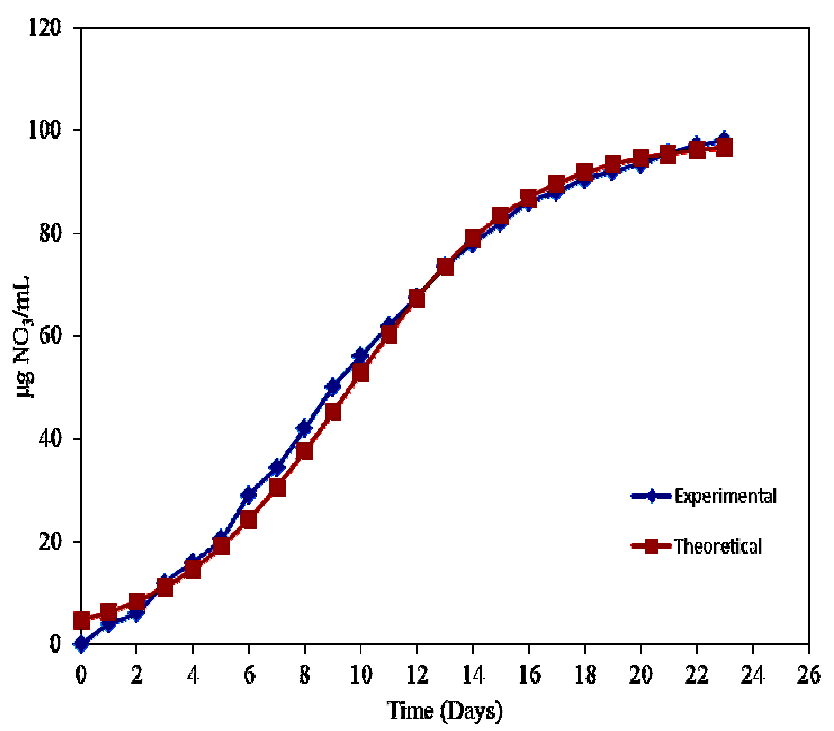

Fig 10. Variation of nitrate formation with time. 
A.E. Ghaly and V.V. Ramakrishnan / American Journal of Agricultural and Biological Science 8 (4): 330-342, 2013

Venterea and Rolston (2000) suggested that initial high levels of $\mathrm{NH}_{4}^{+}$stimulate Nitrosomonas growth which leads to production and accumulation of nitrite $\left(\mathrm{NO}_{2}^{-}\right)$. During this phase, the growth of Nitrobacter is limited by low levels of $\mathrm{NO}_{2}^{-}$. Their results indicated that the Nitrobacter activity begins to increase with increase in the $\mathrm{NO}_{2}^{-}$supplied from the oxidation of ammonium. However, the phenomenon of nitrite accumulation is also attributed to the low density and slow growth rate of Nitrobacter population in the soil.

Burns et al. (1996) and Burns et al. (1995) studied the production of nitrite in soil and reported that the rate of conversion of $\mathrm{NH}_{4}^{+}$to $\mathrm{NO}_{2}^{-}$must be faster than the rate of conversion of $\mathrm{NO}_{2}{ }^{-}$to $\mathrm{NO}_{3}^{-}$. For this phenomenon to occur, the activity of the nitrite oxidizing bacteria must be inhibited and the activity of the ammonium oxidizing bacteria must be increased. These studies showed that the nitrite oxidizing bacteria are very sensitive to high soil $\mathrm{pH}$ and free ammonium concentrations than ammonium oxidizing bacteria. The studies also revealed that high soil $\mathrm{pH}$ and application of urea were found to inhibit the rate of conversion of $\mathrm{NO}_{2}{ }^{-}$to $\mathrm{NO}_{3}{ }^{-}$sufficiently to cause nitrite accumulation. The inhibitory effect of the high $\mathrm{pH}$ is reduced when the amount of ammonium in the soil is reduced due to its conversion to nitrite. At this time, the nitrite oxidizing bacteria become very active and the rate of the conversion of nitrite to nitrate is increased.

\subsection{Nitrate Assimilation/Reduction}

The $\mathrm{pH}$ and nitrate- $\mathrm{N}$ concentration are presented in Table 5. Some bacteria that are ordinarily aerobic can grow anaerobically if nitrate is present. In such cases, nitrate essentially substitutes for oxygen as the final electron acceptor in a respiratory chain. The cell must possess a special enzyme (nitrate reductase) for this function which catalyzes the reaction causing reduction of nitrate to nitrite

$$
\mathrm{N}_{3}^{-}+2 \mathrm{e}^{-}+2 \mathrm{H}^{+} \stackrel{\text { Nitrate Reductase }}{\longrightarrow} \mathrm{NO}_{2}^{-}+\mathrm{H}_{2} \mathrm{O}
$$

Denitrifying microorganisms have an essential requirement for organic carbon as carbon and energy sources. With nitrate respiration, the overall reaction for the oxidation of glucose is:

$$
\mathrm{C}_{6} \mathrm{H}_{12} \mathrm{O}_{6}+12 \mathrm{~N}_{3}^{-} \rightarrow 6 \mathrm{CO}_{2}+6 \mathrm{H}_{2} \mathrm{O}+12 \mathrm{NO}_{2}^{-}
$$

Table 5. Assimilation of nitrate.

\begin{tabular}{ccc}
\hline $\begin{array}{c}\text { Time } \\
\text { (days) }\end{array}$ & $\mathrm{pH}$ & $\begin{array}{c}\mathrm{NO}_{3} \\
(\mu \mathrm{g} / \mathrm{ml})\end{array}$ \\
\hline 0 & 6.9 & 98 \\
1 & 6.9 & 96 \\
2 & 7.0 & 92 \\
3 & 7.1 & 80 \\
4 & 7.2 & 66 \\
5 & 7.3 & 56 \\
6 & 7.4 & 43 \\
7 & 7.5 & 40 \\
8 & 7.5 & 40 \\
9 & 7.5 & 40 \\
\hline
\end{tabular}

The ability to reduce nitrate to nitrite does not, however, permit normal growth under anaerobic conditions, since a large amount of the nitrate must be reduced to oxidize a small amount of the substrate and the reduction product (nitrite) is highly toxic. A few aerobic bacteria, principally Pseudomonas and Bacillus species, can use nitrate as a physiologically useful terminal electron acceptor by reducing it beyond the level of nitrite to molecular nitrogen (Pelczar and Reid, 1972).

$2 \mathrm{NO}_{3}^{-}+10 \mathrm{e}^{-}+12 \mathrm{H}^{+} \rightarrow \mathrm{N}_{2}+6 \mathrm{H}_{2} \mathrm{O}$

In this study, denitrification did not proceed because of the presence of oxygen which prevents the denitrifying organisms from producing the enzyme responsible for the process. In the presence of air (even when nitrate is present), respiration proceeds entirely through the aerobic electron transport chain. The results shown in Figure 11 indicated that about $59 \%$ of the nitrate was reduced. Since the denitrification could not take place under aerobic conditions, the alternative pathway for nitrate reduction could be by assimilatory reduction where nitrate was converted to ammonium and then to cell $-\mathrm{N}$ as follows:

$$
\mathrm{NO}_{3}^{-} \stackrel{\mathrm{NO}_{3} \text { reductease }}{\longrightarrow} \mathrm{NO}_{2} \rightarrow \mathrm{X} \rightarrow \mathrm{NH}_{2} \mathrm{OH} \rightarrow \mathrm{NH}_{4} \rightarrow \text { Cell N }
$$

The removal of nitrate and production of ammonium caused a rise in the $\mathrm{pH}$. The initial $\mathrm{pH}$ of the solution was 6.9 which increased with time reaching 7.3 by the seventh day as shown in Figure 12.

Solomonson and Barber (1990) stated that the assimilatory conditions and nitrate reductase is inactivated by the presence of oxygen. Solomonson and Barber (1990) and Bergaust et al. (2008) indicated that the presence of $\mathrm{NH}_{4}^{+}$prevents the synthesis of the enzyme involved in nitrate reduction. 


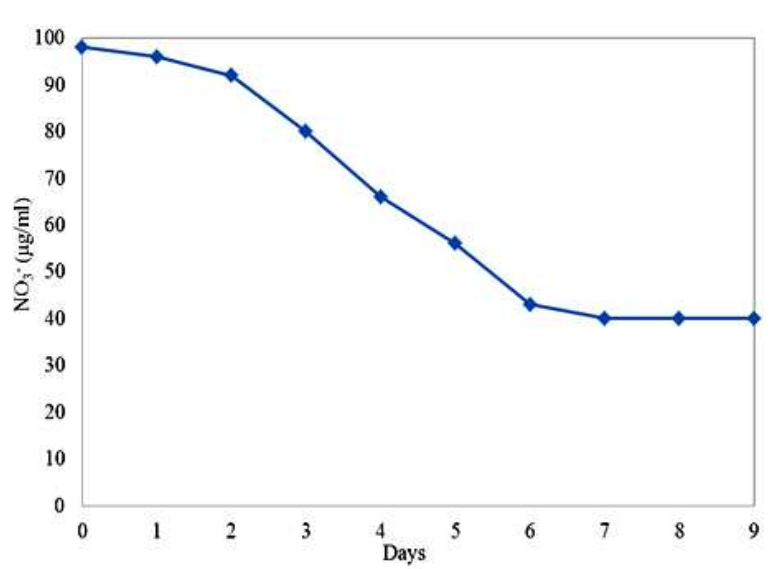

Fig 11. Nitrate disappearance with time during nitrate reduction process.

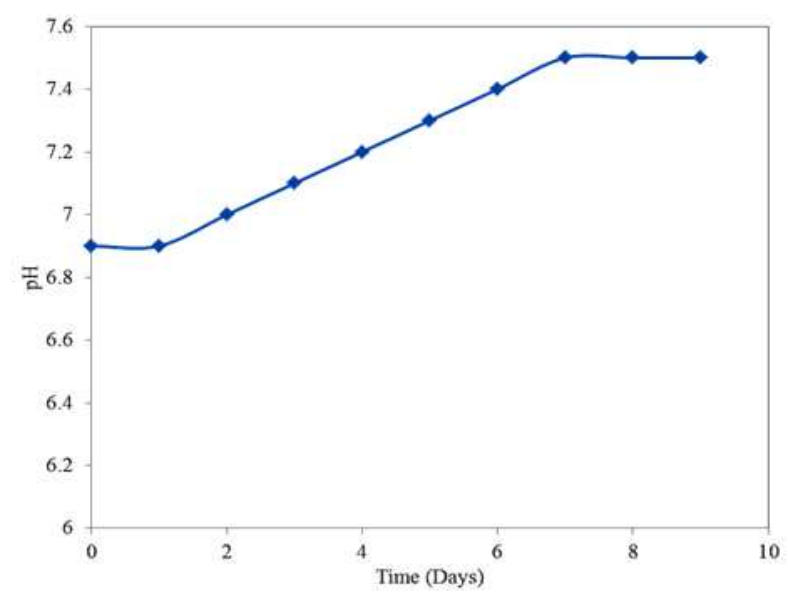

Fig 12. $\mathrm{pH}$ variation with time during nitrate reduction.

Burns et al. (1995) reported that assimilatory reduction on nitrate is bound to happen which would result in reduction to nitrite and then to ammonium and finally forming nitrogen species that is recovered in the microbial biomass.

Alcantara-Hernandez et al. (2009) reported that the assimilatory nitrate pathway is primarily catalyzed by nitrate reductase, in which the nitrate is reduced to ammonium and nitrogen species that can be incorporated into the biomass. This is broadly possible in various fungi, yeast, algae, plants and phototropic and heterotropic bacteria. McCarty and Bremner (1992) studied the assimilatory reduction of nitrate in aerated soil using assimilatory nitrate reductase and observed the uptake of ammonium by microbial cells.

The experiment indicated the reduction of nitrate to cell nitrogen. This was confirmed by the fact that as soon as nitrate was converted into ammonium the later was converted into cell nitrogen and thus the enzyme was protected. According to our assumption, we expected $50 \%$ nitrate reduction but the experimental data showed a $59 \%$ reduction, which suggests that more than $25 \%$ of the glucose-carbon was metabolized and less than $75 \%$ was oxidized.

\section{CONCLUSIONS}

In this study, urea was rapidly nitrified by the bacteria in the saturated soil but its course of transformation to $\mathrm{NO}_{3}$ was not linear. There was an initial increase in the concentration of nitrite during the nitrification experiment which indicated that the conversion of nitrite to nitrate was appreciably slower than the rate of conversion of urea to nitrite. The rate of conversion of $\mathrm{NH}_{4}^{+}$to $\mathrm{NO}_{2}^{-}$was faster than the rate of conversion of $\mathrm{NO}_{2}{ }^{-}$to $\mathrm{NO}_{3}{ }^{-}$in the first 12 days and as a result the nitrate concentration reached $2.72 \mu \mathrm{g} / \mathrm{ml}$ on the $12^{\text {th }}$ day. After day 12, the concentration of $\mathrm{NH}_{4}^{+}$in solution declined significantly and the rate of conversion of $\mathrm{NO}_{2}{ }^{-}$to $\mathrm{NO}_{3}{ }^{-}$became faster than the rate of conversion of $\mathrm{NH}_{4}^{+}$to $\mathrm{NO}_{2}^{-}$. The concentration of $\mathrm{NO}_{2}-\mathrm{N}$ in the solution reached zero on the $23^{\text {rd }}$ day. The nitrification curve has the character of a sigmoid curve whose midpoint, which representing the most rapid rate of nitrification, fell at the point of half conversion of urea to nitrite. The curve asymptotically approaches a nitrate value that represents $98 \%$ conversion of urea into nitrate. The rest of the urea $\left(\mathrm{NH}_{4}\right)$ has presumably been synthesized into bacterial cells. The initial $\mathrm{pH}$ of the soil was 7.7 due to the presence of $\mathrm{NH}_{4}$ which decreased gradually due to the production of $\mathrm{NO}_{3}$ reaching 6.9 by day 23. A nitrate reduction was observed under aerobic conditions. Denitrification did not proceed according to the known fact that $\mathrm{O}_{2}$ prevents the denitrifying organisms from producing the enzyme responsible for the process. The alternative pathway for nitrate reduction could be by assimilatory reduction where nitrate was converted to ammonium and then to cells. The removal of nitrate and production of ammonium caused a rise in the $\mathrm{pH}$. The initial $\mathrm{pH}$ of the solution was 6.9 which increased with time reaching 7.3 by the $7^{\text {th }}$ day. The expected nitrate reduction was $50 \%$ according to the 
assumption, but the $59 \%$ nitrate reduction observed in the experiment suggests that more than $25 \%$ of glucose $\mathrm{C}$ was metabolized and less than $75 \%$ was oxidized, otherwise.

\section{ACKNOWLEDGEMENT}

The research was supported by the Natural Sciences and Engineering Research Council (NSERC) of Canada.

\section{REFERENCES}

Alcantara-Hernandez, R. J., C. Valenzuela-Encinas, F. J. Zavala-Diaz de la Serna, J. Rodriguez-Revilla, L. Dendooven and R. Marsch, 2009. Haloarcheal assimilatory nitrate-reducing communities from a saline alkaline soil. FEMS Microbiology Letters, 298: 56-66.

APHA, 1990. Standard Methods for Examination of Water and Wastewater, Washington, DC. USA.

Bentley, M.L., 1953. Enzymes of pathogenic fungi. Journal of General Microbiology, 8: 365-377.

Bergaust, L., J. Shapleigh, A. Frostegard and L. Bakken, 2008. Transcription and activities of $\mathrm{NO}_{\mathrm{x}}$ reductases in Agrobacterium tumefaciens: the influence of nitrate, nitrite and oxygen availability. Environmental Microbiology, 10(11): 3070-3081. DOI: 10.111/j.1462-2920.2007.01557.x.

Billen, G., 1976. Evaluation of nitrifying activity in sediments by dark 14C-bicarbonate incorporation. Water Research, 10(1): 51-57. DOI: 10.1016/00431254(76)90157-3.

Burns, L. C., R. J. Stevens and R. J. Laughlin, 1995. Determination of the simultaneous production and consumption of soil nitrite using ${ }^{15} \mathrm{~N}$. Soil Biology and Biochemistry, 27(6): 839-844.

Burns, L. C., R. J. Stevens and R. J. Laughlin, 1996. Production of nitrite in soil by simultaneous nitrification and denitrification. Soil Biology and Biochemistry, 28 (4/5): 609-616.

Challa, A., S. Johnson., K. Robertson and M. Gunasekaran, 1999. Properties of adenosine deaminase from Canadida albicans. Journal of Basic Microbiology, 39(2): 97-101.

Chen, R. L., D. R. Keeney and J. G. Konrad, 1972. Nitrification in sediments of selected Wisconsin lakes. Journal of Environmental quality, 1(2): 151154.

DOI: $10.2134 /$ jeq1972.00472425000100020010x.
Cranfield, D. E., A. N. Glazer and P. G. Falkowski, 2010. The evolution and fiture of the earth's nitrogen cycle. Science, 330: 192-197. DOI: 10.1126/science/.1186120.

Delwiche, C. C. and M. S. Finstein, 1965. Carbon and energy sources for the nitrifying autotroph nitrobacter. Journal of Bacteriology, 90:120-107.

Fuka, M. M., M. Engel, A. Hafen, J. C. Munch, M. Sommer and M. Schloter, 2009. Changes of diversity pattern of proteolytic bacteria over time and space in an agricultural soil. Microbial Ecology, 57: 391-401. DOI: $10.1007 / \mathrm{s} 00248-008-9416-6$.

Gottlieb, D. and Ciferri, 1956. Deamination and degradation of amino acids by Streptomycetes. Mycologia, 48 (2): 253-263.

Hofmockel, K. S. N. Fierer, B. P. Coleman and R. B. Jackson, 2010. Amino acid abundance and proteolytic potential in North American soils. Ecosystem Ecology, 163(4): 1069-1078. DOI: 10.1007/s00442-010-1601-9.

Jetten, M. S. M., 2008. Editorial: The microbial nitrogen cycle. Environmental Microbiology, 10(11): 29032909. DOI: 10.111/j.1462-2920.2008.01786.x.

Kamala-Kannan, S., K. J. Lee, S. M. Park, J.-C. Chae, B. S. Yun, Y. H. Lee, Y. J. Park and B. T. Oh, 2010. Characterization of Acc deaminase gene in Pseudomonas entomophila strain PS-PJH isolated from the rhizosphere soil. Journal of Basic Microbiology, 50(2): 200-205. DOI: 10.1002/jobm.200900171.

Keeney, D. R., 1973. The nitrogen cycle in sediment water systems. Journal of Environmental Quality 2(1): 15-29. DOI: 10.2134/jeq1973.00472425000200010002x.

Kim, M., S. Y. Jeong, S. J. Yoon, S. J. Cho, Y. H. Kim, M. J. Kim, E. Y. Ryu and S. J. Lee, 2008. Aerobic denitrification of Pseudomonas putida AD-21 at different $\mathrm{C} / \mathrm{N}$ ratios. Journal of Bioscience and Bioengineering, 106(5): 498-502. DOI: 10.1263/jbb.106.498.

Kunert, J., 1982. Utilization of L- and DL- cystine by the fungus Microsporum gypseum. Folia Microbiology, 27: 390-394.

Kyveryga, P. M., A. M. Blackmer, J. W. Ellsworth and R. Isla, 2004. Soil pH effects on nitrification of fall applied anhydrous ammonia. Soil Science Society of America Journal, 68: 545-551. 
Li, H., Y. Xhang, M. Yang and Y. Kamagata, 2013. Effects of hydraulic retention time on nitrification activities and population dynamics of a conventional activated sludge system. Fronteirs of Environmental Science and Engineering, 7(1): 43-48. DOI: 10.1007/s11782-012-0397-8.

Lin, Y. M., J. H. Tay, Y. Liu and Y. T. Hung, 2009. Biological nitrification and denitrification processes. Biological Treatment Processes, 8: 539-588. DOI: 10.1007/978-1-603270156-1 13.

McCarty, G. W. and J. M. Bremner, 1992. Regulation of assimilatory nitrate reductase activity in soil by microbial assimilation of ammonium. Proceedings of the National Academy of Sciences, 89: 453-456.

Ohshima, T., H. Misono and K. Soda, 1978. Properties of crystalline leucine dehydrogenase from Bacillus sphaericus. The Journal of Biological Chemistry, 253(16): 5719-5725.

Ohshima, T., H. Takada., T. Yoshimura, N. Esaki and K. Soda, 1991. Distribution, purification, and characterization of thermostable phenylalanine dehydrogenase from thermophilic actinomycetes. Journal of Bacteriology, 173(13): 3943-3948.

Pelczar, M. J. and R. D. Reid, 1972. Microbiology (Third Edition). McGraw Hill Book Company. NewYork. ISBN: 0070492263.

Robertson, G. P. and P. M. Vitousek, 2009. Nitrogen in agriculture: Balancing the cost of an essential resource. Annual Review of Environment and Resources, 39: 97-2005. DOI: 10.1146/annurev.environ.032108.105046.

Robertson, L. A. and J. G. Kuenen, 1990. Combined heterotrophic nitrification and aerobic denitrification in Thioshaera pantotropha and other bacteris. Antonie van Leuewenhoek, 57(3): 139-152. DOI: 10.1007/BF00403948.

Sahrawat, K. L., 1982. Nitrification in some tropical soils. Plant and Soil, 57: 143-146.

Sahrawat, K. L., 2008. Factors affecting nitrification in soils. Communications in Soil Science and Plant Analysis, 39: 1436-1446. DOI: $10.1080 / 00103620802004235$.

Sahrawat, K. L., D. R. Keeney and S. S. Adams, 1985. Rate of aerobic nitrogen transformations in six acid climax forest soils and the effect of phosphorous and $\mathrm{CaCO}_{3}$. Forest Science, 31(3): 680-684.
Simek, M. and J. E. Cooper, 2002. The influence of soil $\mathrm{pH}$ on denitrification: progress towards the understanding of this interaction over the last 50 years. European Journal of Soil Science, 53: 345-354.

Smith, M. J., A. N. Masse, A. W. Feige and L. J. Kamphake, 1972. Nitrogen removal from municipal waste water by columnar denitrification. Environmental Science and Technology, 6 (3):260267. DOI: $10.1021 / \mathrm{es} 60062 \mathrm{a} 005$.

Smith, R. V., R. M. Doyle, L. C. Burns and R. J. Stevens, 1997. A model for nitrite accumulation in soils. Soil Biology and Biochemistry, 29(8): 12411247.

Solomonson, L. P. and M. J. Barber, 1990. Assimilatory nitrate reductase: functional properties and regulation. Annual Review of Plant Physiology and Plant Molecular Biology, 41: 225-253. DOI: 10.1146/annurev.pp.41.060190.001301.

Takikawa, S., C. K. Yokokawa and M. Tsusue, 1979. Ptrein deaminase from Bacillus megaterium. Journal of Biochemistry, 85: 785-790.

Torrento, C., J. Cama, j. Urmeneta, N. Otero and A. Soler, 2010. Denitrification of groundwater with pyrite and Thiobacillus denitrificans. Chemical Geology, 278(1-2): 80-91. DOI: 10.1016/j.chemgeo.2010.09.003.

Van Cleemput, O and A. Samater, 1996. Nitrite in soils: Accumulation and role in the formation of gaseous $\mathrm{N}$ compounds. Fertilizer Research, 45: 81-89.

Venterea, R. T. and D. E. Rolston, 2000. Mechanistic modeling of nitrate accumulation and nitrogen oxide gas emissions during nitrification. Journal of Environmental Quality, 29: 1741-1751.

Warneke, S., L. A. Schipper, M. G. Matiasek, K. M. Scow, S. Cameron, D. A. Bruesewitz and I. R. McDonald, 2011. Nitrate removal, communities of denitrifiers and adverse effects in different carbon substrates for use in denitrification beds. Water Resources, 45(17): 5463-5475. DOI: 10.1016/j.watres.2011.08.007. 